\title{
PENGEMBANGAN KAWASAN AGROWISATA BUAHTERPADU DI KECAMATAN LIKUPANG SELATAN KABUPATEN MINAHASA UTARA
}

\author{
Ingerid Lidia Moniaga ${ }^{1),}$ Josephine L.P.Saerang ${ }^{2)}$, Sukmarayu P. Gedoan ${ }^{3)}$ \\ 1)Fakultas Teknik Universitas Sam Ratulangi \\ E-mail : ingeridmoniaga73@gmail.com \\ 2)Fakultas Peternakan Universitas Sam Ratulangi \\ E-mail : pinky_saerang@yahoo.com \\ ${ }^{3)}$ Fakultas Matematika dan Ilmu Pengetahuan Alam Universitas Manado \\ E-mail : sgedoan@gmail.com
}

\begin{abstract}
ABSTRAK
Kabupaten Minahasa Utara merupakan salah satu kabupaten di Provinsi Sulawesi Utara. Pengembangan wilayah Kecamatan Likupang Selatan yang tertuang dalam program wilayah Kabupaten Minahasa Utara yakni dalam Rencana Pembangunan Jangka Menengah Daerah (RPJMD), merupakan wilayah yang dikembangkan sebagai Kawasan Agrowisata Buah. Metode pelaksanaan kegiatan Pengabdian Kepada Masyarakat ini, yaitu memberi pembinaan dan pendampingan pada masyarakat di wilayah Kecamatan Likupang Selatan dalam Pengembangan kawasan agrowisata buah-buahan. Pembinaan dan pendampingan yang dilakukan untuk menangani beberapa masalah prioritas yang dilakukan dengan tahapan diantaranya Penyuluhan dan Pelatihan.

Tujuan yang ingin dicapai dari kegiatan Ipteks bagi Wilayah yaknipengembangan kawasan agrowisata buah-buahan yang memanfaatkan potensi pertanian, dan pemberdayaan masyarakat berbasis pariwisata (community based tourism). Pemberdayaan masyarakat yang dimaksud yaitu agrowisata yang dapat mengikutsertakan peran dan aspirasi masyarakat pedesaan selaras dengan pendayagunaan potensi sumber daya alam dan sumber daya manusia yang dimiliki di wilayah tersebut.Tujuan lainnyadengan terwujudnya kawasan agrowisata buah-buahan di wilayah Kecamatan Likupang Selatan yang diimplementasikan dalam penataan objek rekreasi dan wisata, maka diharapkan objek tersebut akan menjadi landmark (penanda suatu kawasan) yang dapat dikenali oleh segenap lapisan masyarakat di Provinsi Sulawesi Utara umumnya dan Kabupaten Minahasa Utara secara khususnya.
\end{abstract}

Kata Kunci : pengembangan kawasan, agrowisata buah, sumber daya manusia

\section{PENDAHULUAN}

\section{Analisis Situasi}

Kabupaten Minahasa Utara merupakan

salah satu kabupaten di Provinsi Sulawesi

Utara. Luas wilayah Kabupaten Minahasa Utara

adalah sekitar 1.059.244 $\mathrm{km}^{2}$.Kabupaten

Minahasa Utara terdiri dari 10 kecamatan,

yaitu:Airmadidi, Kalawat, Dimembe, Talawaan, $\underline{\text { Kauditan, Kema, Likupang Barat, Likupang }}$

Selatan, Likupang Timur, dan $\underline{\text { Wori }}$

(Bapelitbang, 2014). Pengembangan wilayah

Kecamatan Likupang Selatan yang tertuang

dalam program wilayah Kabupaten Minahasa

Utara yakni dalam Rencana Pembangunan

Jangka Menengah Daerah (RPJMD),

merupakan wilayah yang dikembangkan 
sebagai Kawasan Agrowisata Buah. Program wilayah yang menetapkan Kecamatan Likupang Selatan sebagai Kawasan Agrowisata Buah, karena pada wilayah ini terdapat potensi pertanian yang mengembangkan tanaman pangan, hortikultura, perkebunan, dan peternakan.Tanaman pertanian hortikultura buah-buah yang banyak dijumpai diwilayah ini yaitu Durian, Langsat, Duku, Rambutan, Manggis, dan Mangga.Tanaman-tanaman tropis tersebut yang produktif berbuah setiap tahunnya, juga dibudidayakan/kembangkan oleh masyarakat setempat melalui sistem pekarangan campuran.Sistem pekarangan campuran yang dimaksud ialah sistem pertanian di lahan pekarangan masyarakat yang dalam pola tanamnya bercampur antara satu jenis tanaman buah dengan jenis tanaman buah lainnya.Sedangkan konsep pengembangan lansekap kawasan agrowisata yang hendak dikembangkan di wilayah Kecamatan Likupang Selatan yakni konsep pengembangan zonasi berdasarkan jenis buah-buahan yang ada.

Penduduk di Kecamatan Likupang Selatan banyak yang bercocok tanam jenis tanaman tahunan seperti buah-buahan maupun tanaman perkebunan lainnya. Kecamatan Likupang Selatan dikenal dengan daerah penghasil buahbuahan seperti langsat, rambutan, dan durian. Sedangkan untuk peternakan, yang menjadi unggulan adalah ayam, itik, dan babi.
Ketenagakerjaan di Kecamatan Likupang Selatan masih didominasi dari sektor pertanian. Beberapa permasalahan pokok di sektor pertanian Kecamatan Likupang Selatandiantaranya :masih rendahtingkat pendapatan petani disebabkan belum adanya upaya pengembangan potensi sumberdaya hayati secara lokal di bidang pertanian dan peternakan, rendahnya animo masyarakat terutama kaum muda untuk menjadi petani dan cenderung lebih memilih untuk berurbanisasi atau mencari pekerjaan di luar kampung halamannya, tingginya pengangguran sebagai akibat kurangnya bekal pengetahuan teknis dan keterampilan (life skill), usaha ternak yang dijalankan belum memberikan hasil yang nyata akibat pola pemeliharaan ternak yang menggantungkan kebutuhan pakan pada pakan buatan yang mahal dan kadang tidak tersedia secara kontinyu, kurangnya pengetahuan dan keterampilan peternak tentang jenis-jenis bahan baku pakan alternatif, kurangnya pengetahuan masyarakat tentang pengelolaan agribisnis bidang pertanian, kurangnya pengetahuan dan keterampilan masyarakat dalam mengolah pupuk organik dengan memanfaatkan potensi bahan organik seperti limbah pertanian dan peternakan, belum adanya wadah kewirusahaan yang difokuskan pada usaha kecil, pertanian, peternakan, dan kerajinan dengan 
memanfaatkan potensi sumberdaya hayati yang tersedia secara lokal.

Hasil pra survey Tim Fakultas Peternakan bulan April 2012, menunjukkan bahwa masalah yang dihadapi oleh petani peternak adalah masalah pakan. Selama ini ternak sapi mengkonsumsi rumput yang tumbuh liar ataupun limbah pertanian yang kualitasnya rendah. Hal ini yang menyebabkan produktivitas ternak sapi sangat rendah. Berat badan ternak sapi lebih rendah dibanding dengan ternak sapi di daerah lain yang mengkonsumsi rumput berkualitas untuk umur dan jenis ternak sapi yang sama. Dalam menghadapi permasalahan tersebut, perlu introduksi hijauan berkualitas di daerah tersebut. Tetapi, bagaimana manajemen hijauan makanan ternak belum diketahui oleh petani peternak sapi. Berapa kebutuhan setiap ekor, cara menanam, kapan rumput dipotong perlu diketahui oleh petani peternak. Pemerintah wajib untuk membuat suatu percontohan dan disosialisasikan kepada masyarakat petani peternak sapi. Kotoran ternak dapat dimanfaatkan sebagai pupuk untuk lahan pertanian oleh petani peternak. Pemberian pupuk kompos dapat meningkatkan dan mempertahankan keanekaragaman dan kehidupan organisme tanah. Pupuk kandang merupakan pupuk dari hasil fermentasi kotoran padat dan cair (urine) dari ternak sapi.
Sedangkan pupuk kompos adalah pupuk yang dibuat dari berbagai limbah dan gulma. Pemasalahannya kotoran ternak belum dimanfaatkan oleh petani peternaktersebut sebagai pupuk kompos.Pupuk kompos dapat bermanfaat sebagai sumber pendapatan alternatif bagipetani peternak.

\section{Bidang Pariwisata}

Potensi kawasan pariwisata di wilayah Kabupaten Minahasa Utara yaitu kawasan yang memiliki potensi obyek dan daya tarik wisata alam, wisata budaya, wisata agro, dan wisata lainnya baik yang sudah berkembang maupun yang belum berkembang. Wilayah Kecamatan Likupang Selatan merupakan salah satu kecamatan yang memiliki potensi untuk dikembangkan agrowisata, tetapi belum ada sumber daya manusia yang mampu merencanakan, mendesain, dan mengelola dengan baik.Data Dinas Kebudayaan dan Pariwisata Kabupaten Minahasa Utara Tahun 2012 menunjukkan bahwa Kecamatan Likupang Selatan belum memiliki objek wisata yang dapat diandalkan. 


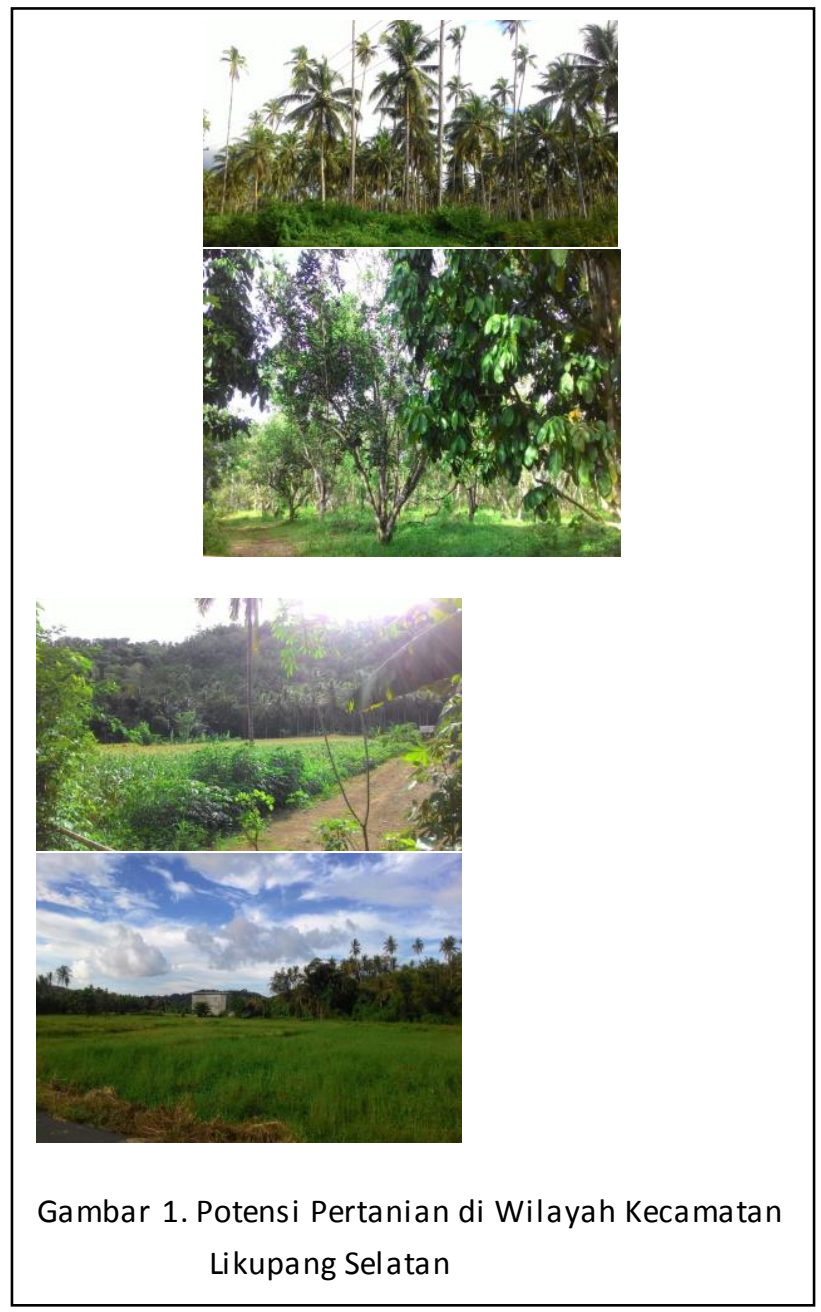

\section{PERMASALAHAN MITRA}

\section{Bidang Pertanian}

(1) Mengatasi masalah rendahnyatingkat pendapatan petani disebabkan belum adanya upaya pengembangan potensi sumberdaya hayati secara lokal di bidang pertanian, peternakan, dan perkebunan

(2) Mengatasi masalah kurangnya ketrampilan dan pengetahuan anggota kelompok masyarakat dalam menata dan meningkatkan keragaman produksi tanaman pertanian

(3) Mengatasi masalah rendahnya produktivitas usaha ternak melalui upaya pemberian pengetahuan dan keterampilan memformulasi pakan berbasis potensi sumberdaya hayati yang tersedia secara lokal

(4) Mengatasi masalah kelangkaan dan mahalnya harga pupuk melalui usaha pengolahan pupuk organik dengan memanfaatkan potensi bahan organik seperti limbah pertanian dan peternakan yang melimpah dan dibiarkan begitu saja.

\section{Bidang Pariwis ata}

(1) Menata daerah pertanian peternakan di Kecamatan Likupang Selatan untuk menjadi suatu kawasan agro wisata

(2) Meningkatkan kesadaran masyarakat dalam menjaga dan melestarikanobyek wisata.

\section{SOLUSI DAN TARGET LUARAN}


Solusi dan target luaran yang ingin dicapai pada pembinaan dan pendampingan kelompok masyarakat Kecamatan Likupang Selatan Kabupaten Minahasa Utara adalah (1) meningkatnya pengetahuan masyarakat dalam Pengembangan Potensi Sumber Daya Alam yang bisa dikembangkan sebagai Kawasan

Agrowisata Buah, (2) memahami dan melakukan kegiatan praktek mengembangkan

kawasan agrowisata, (3) memiliki kemampuan dalam mengelola kawasan agrowisata, (4) meningkatkan pemanfaatan ruang wilayah sebagai kawasan agrowisata buah, (5) menghasilkan artikel ilmiah yang dapat dipublikasikan pada jurnal akreditasi.

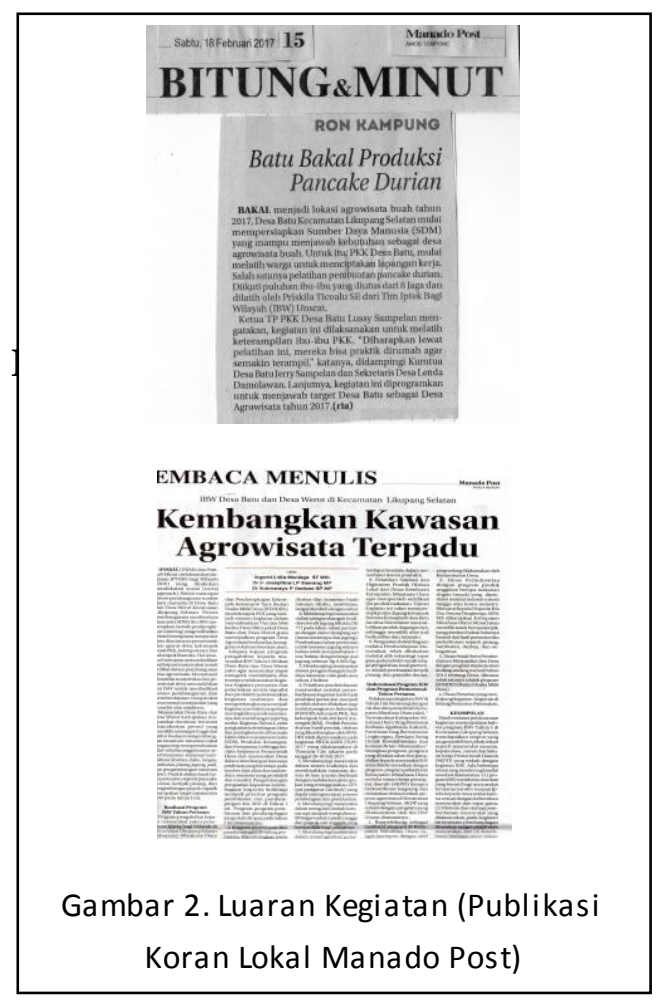

Berdasarkan permasalahan kelompok mitramaka metode pelaksanaan kegiatan pengabdian kepada masyarakat dilakukan dengan cara pembinaan dan pendampingan terhadap kelompok tersebut. Pembinaan dan pendampingan yang dilakukan untuk menangani beberapa masalah prioritas diantaranya seperti tertera pada tabel 1 dan gambar 3di bawah ini : 
Tabel 1. Pelaksanaan Pembinaan dan Pendampingan

\begin{tabular}{|c|c|c|}
\hline \multirow[t]{2}{*}{ No } & Pembinaan & $\begin{array}{l}\text { Pelatihan/Pendampi } \\
\text { ngan }\end{array}$ \\
\hline & \multicolumn{2}{|c|}{ Bidang Pertanian } \\
\hline 1 & $\begin{array}{l}\text { Melakukan } \\
\text { penyuluhan dan } \\
\text { Pilot Project } \\
\text { untuk budidaya } \\
\text { tanaman } \\
\text { holtikultura } \\
\text { (durian) }\end{array}$ & $\begin{array}{l}\text { - Pelatihan } \\
\text { budidaya buah } \\
\text { unggulan } \\
\text { - Pelatihan sistem } \\
\text { pembuahan } \\
\text { tanaman }\end{array}$ \\
\hline 2 & $\begin{array}{l}\text { Penyuluhan dan } \\
\text { pelatihan } \\
\text { pembuatan } \\
\text { pupuk organik } \\
\text { berbasis limbah } \\
\text { pertanian dan } \\
\text { rumah tangga }\end{array}$ & $\begin{array}{l}\text { - Pelatihan } \\
\text { teknologi } \\
\text { pengolahan } \\
\text { pupuk organik } \\
\text { - Pelatihan } \\
\text { Introduksi } \\
\text { teknologi } \\
\text { pengolahan } \\
\text { pakan ternak dari } \\
\text { limbahpertanian } \\
\end{array}$ \\
\hline 3 & $\begin{array}{l}\text { Pelatihan Hasil- } \\
\text { Hasil Pertanian }\end{array}$ & $\begin{array}{l}\text { - Pelatihan Produk } \\
\text { Olahan Hasil- } \\
\text { Hasil Pertanian } \\
\text { (Pancake Durian, } \\
\text { Keripik Pisang) }\end{array}$ \\
\hline \multicolumn{3}{|c|}{ Bidang Peternakan } \\
\hline 1 & $\begin{array}{l}\text { Melakukan } \\
\text { penyuluhan dan } \\
\text { pilot Project } \\
\text { usaha ternak }\end{array}$ & $\begin{array}{l}\text { - Pelatihan } \\
\text { Peningkatan } \\
\text { produktivitas } \\
\text { ternak ayam } \\
\text { petelur dan ayam } \\
\text { daging } \\
\text { - Pelatihan } \\
\text { pembuatan biogas }\end{array}$ \\
\hline 2 & $\begin{array}{l}\text { Penyuluhan dan } \\
\text { pelatihan } \\
\text { formulasi pakan } \\
\text { ternak berbahan } \\
\text { lokal }\end{array}$ & $\begin{array}{l}\text { - Pelatihan } \\
\text { pengolahan pakan } \\
\text { ternak }\end{array}$ \\
\hline & \multicolumn{2}{|c|}{ Bidang Pariwisata } \\
\hline 1 & $\begin{array}{l}\text { Penyuluhan } \\
\text { Agrowisata }\end{array}$ & $\begin{array}{l}\text { - Sosialisasi/Disem } \\
\text { inasi tentang } \\
\text { program IbW } \\
\text { - FGD dengan } \\
\text { masyarakat dan } \\
\text { Pemerintah } \\
\text { Daerah } \\
\end{array}$ \\
\hline 2 & $\begin{array}{l}\text { Penyuluhan } \\
\text { pengelolaan } \\
\text { kawasan wis ata } \\
\text { agrowisata }\end{array}$ & $\begin{array}{l}\text { - Penyuluhan Peran } \\
\text { serta masyarakat } \\
\text { menjaga dan } \\
\text { melestarikan } \\
\text { objek wisata }\end{array}$ \\
\hline
\end{tabular}

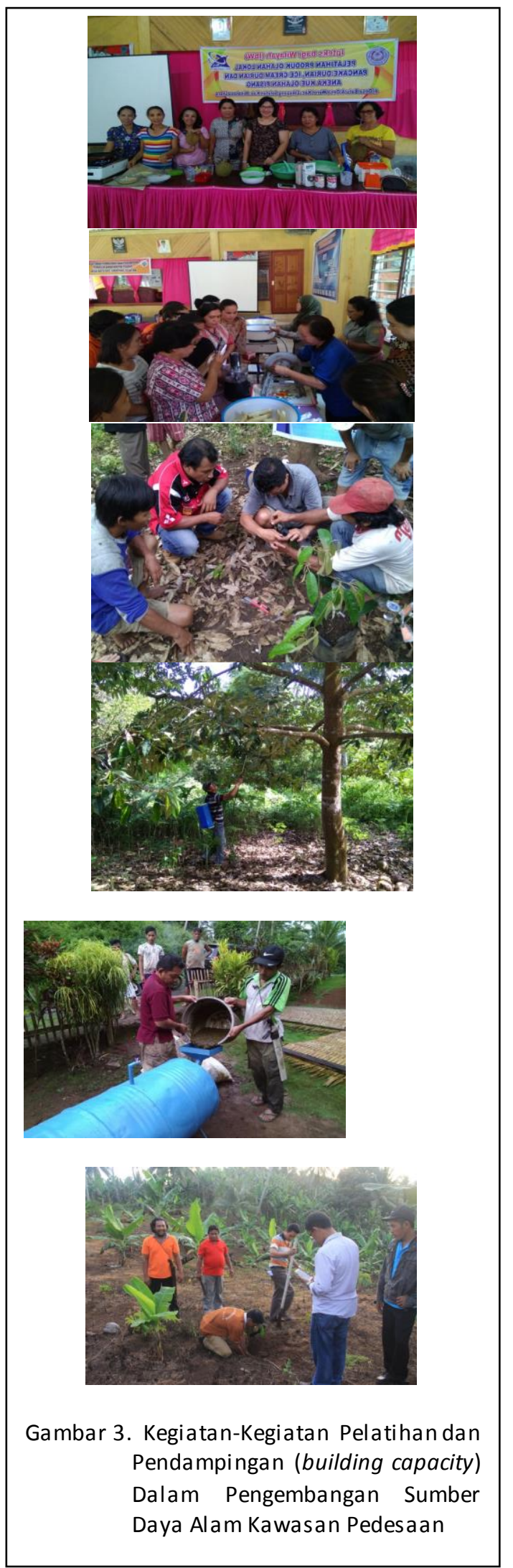




\section{PEMBAHASAN}

\section{Hasil Capaian Program Tahun Pertama}

Pada tahun I kegiatan IbW dilakukan pendekatan sosial (social approach) dalam mencapai proses pembangunan sumberdaya manusia (SDM)di desa Batu dan desa Werot Kecamatan Likupang Selatan. Dalam proses pembangunan SDM tim IbW menerapkan metode pendampingan (sistering) yang melibatkan seluruh komponen masyarakat desa diantaranya pemerintah dan aparat desa, kelompok sosial PKK, kelompok tani, dan kelompok Bumdes. Hal tersebut bertujuan menumbuhkan partisipasi masyarakat untuk terlibat dalam pembangunan desa agrowisata. Memahami dinamika masyarakat dan pemerintah desa memudahkan tim IbW untuk menfasilitasi proses pembangunan dan pemberdayaan masyarakat desa menuju masyarakat yang mandiri dan sejahtera.

Masyarakat desa Batu dan desa Werot merupakan masyarakat dominan bermata pencaharian petani yang memiliki semangat tinggi dan kultur budaya mengembangkan tanaman-tanaman lokal dengan tetap mempertahankan nilai-nilai keunggulannya seperti tanaman-tanaman hortikultura (durian, duku, langsa, rambutan, pisang, jagung, padi, dan pengembangan tanaman cabe). Produk olahan hasil-hasil pertanian seperti pancake durian, keripik pisang, dan pengembangan pupuk organik merupakan target capaian tim IbW pada tahun I ini.

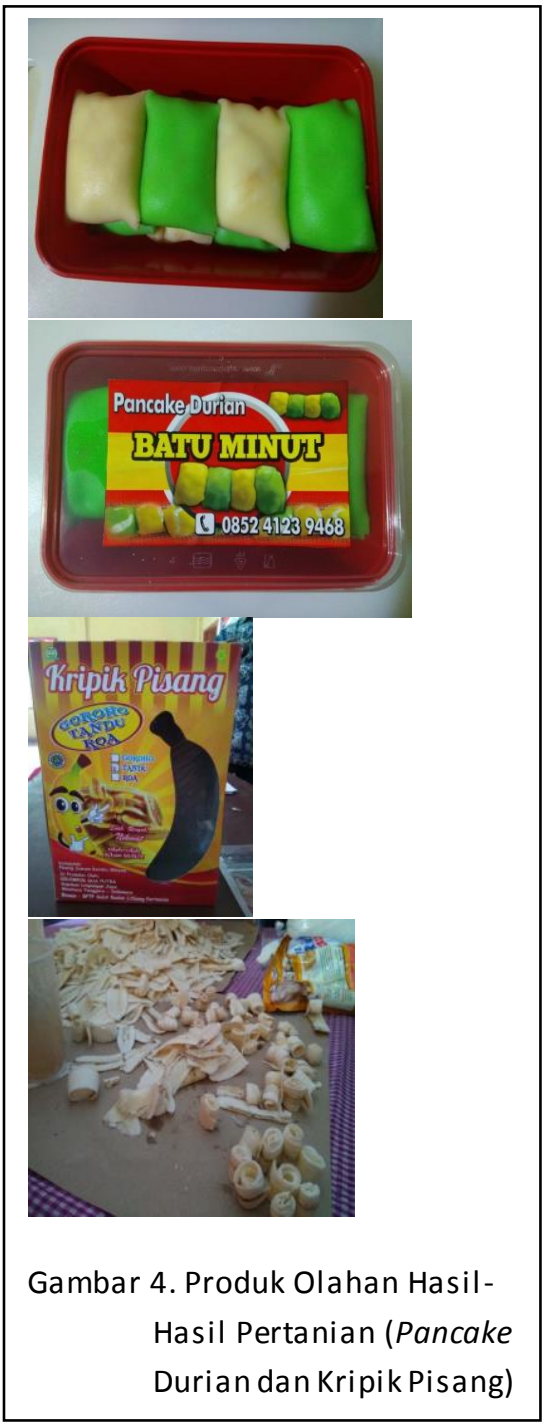

Implementasi Program IbW Tahun Pertama

Program pengabdian kepada masyarakat yakni penerapan Ipteks bagi Wilayah di Kecamatan Likupang Selatan Kabupaten Minahasa Utara Tahun I (Tahun 2017) telah 
Jurnal ABDIMAS, Vol. 10, No. 2, Desember 2017

ISSN: 1979-0953

dilaksanakan dengan pelaksanaan programprogram di bidang pertanian, peternakan, dan pariwisata. Adapun kegiatan-kegiatan yang dilaksanakan secara umum diantaranya Pembinaan dan Pendampingan KelompokKelompok Tani, Badan Usaha Milik Desa (BUMDES), dan kelompok PKK yang menjadi sasaran kegiatan dalam merealisasikan Visi dan Misi kedua Desa Mitra yakni Desa Batu dan Desa Werot guna mewujudkan program Desa Agrowisata berdasarkan keunggulan lokal sumberdaya alam.

Adapun tujuan program pengabdian kepada masyarakat IbW Tahun I di lokasi Desa Batu dan Desa Werot yaitu agar masyarakat dapat mengerti, memahami, dan mampu melaksanakan kegiatan-kegiatan pertanian dan peternakan secara mandiri dan produktif melaksanakan kegiatan usahanya dan mengembangkannya menjadi kegiatan produksi yang dapat meningkatkan perekonomiannya dan membangun jejaring usaha.Kegiatan Tahun I, yaitu penguatan kelembagaan desa dan peningkatan kualitas pada faktor-faktor manajemen usaha (SDM, Produksi, dan Pemasaran) sehingga tercipta kerjasama Pemerintah Desa dan masyarakat Desa dalam membangun kawasan perdesaan yang bertumpu pada sumber daya alam dan sumberdaya manusia yang produktif dan mandiri. Pengembangan penguatan kapasitas kelembagaan (capacity building) menjadi prioritas program pembinaan dan pendampingan tim IbW di Tahun I ini. Program-program pembinaan dan pendampingan yang telah dicapai pada tahun I ini diantaranya :

1. Kegiatan pembinaan dan pendampingan di bidang pertanian, dikembangkan pada tanaman buah unggul lokal durian dan tanaman perkebunan pisang, jagung, dan tanaman cabe. Desa Batu dan Desa Werot merupakan sentra produksi tanaman durian di Kabupaten Minahasa Utara. Di kedua desa ini tanaman durian dan tanaman buah lainnya (duku, rambutan, langsa) tumbuh dengan subur. Namun sistem perbanyakan tanaman masih menggunakan biji (generatif) sehingga masa tanam dan berbuah membutuhkan waktu yang cukup panjang (8-10 tahun).Untuk memproduksi bibit unggul lokal desa Batu dan desa Werot yang diambil dari materi pohon durian unggul, masyarakat belum memiliki teknik, kecuali cangkok yang sudah dikenal luas dimasyarakat. Namun untuk memproduksi secara komersial, mereka perlu diberikan pelatihan perbanyakan tanaman secara grafting/sambung.Penyebarluasan dan teknologi grafting dalam rangka peremajaan bibit durian unggul lokal dilakukan agar masyarakat bisa memproduksi bibit-bibit 
durian lokal dengan waktu berbuah yang singkat (3-4 tahun). Penyebarluasan teknik grafting dilakukan pada area perkebunan buah-buahan dan pembibitan desa Batu dan desa Werot. Kelompok tani yang terdiri dari aparat desa difasilitasi dan dibimbing dalam melakukan grafting. Teknikgrafting/sambung tampaknya mudah, namun memerlukan banyak syarat yang mesti dipenuhi agar keberhasilannya memuaskan.Dari 15 jumlah peserta pelatihan, hanya 3 orang yang dapat melakukan teknik grafting. Kelompok tani di kedua desa tersebut masih perlu didampingi agar keberhasilannya semakin tinggi. Jenis durian yang digrafting dipilih yang bernilai ekonomi tinggi, misalnya jenis Panada, Mentega, Cakalang, Belanga, Susu dan sebagainya. Pelatihan budidaya pembuatan bibit unggul, pembukaan kebun percontohan budidaya, penanaman dan pembukaan kebun durian baru berdasarkan jenis-jenis unggul lokal yang ditata sesuai pengkasifikasian zone/area.

2. Mendampingi masyarakat dalam pengembangan budidaya benih jagung hibrida DK 771 pada lahan-lahan pertanian dengan sistem tumpang sari (tanaman kelapa dan jagung). Pembukaan lahan pertanian untuk tanaman jagung seluas 6 hektar telah memproduksi 6-7 ton/hektar dengan harga jual jagung sebesar Rp 6.000/kg. Manfaat tanaman jagung saling terkait dengan pengolahan pakan ternak seperti pakan ayam yang menggunakan bahan baku tanaman jagung. Hal ini memudahkan petani dalam penyediaan pakan ternak yang berbahan lokal dan menghemat penggunaan pakan berbahan konsentrat.

3. Mendampingi masyarakat dalam pengembangan budidaya tanaman cabe pada area seluas 2 hektar.

4. Pelatihan pemberdayaan masyarakat melalui penyebarluasan kegiatan hasil-hasil produksi pertanian menjadi produk olahan dilakukan juga melalui penguatan kelompok BUMDES, kelompok PKK, dan kelompok industri kecil menengah (IKM). Pelatihanpelatihan produk olahan lokal yang dilakukan antara lain ; Pelatihan Pancake Durian, dan Keripik Pisang. Kegiatan ini bertujuan menfasilitasi pembangunan partisipatif yang bernilai guna dalam mencapai kemandirian dan peningkatan ekonomi kerakyatan.Penguatan kelembagaan kelompok BUMDES telah mencapai tahap produksi dan promosi. Produk Pancake Durian hasil produk olahan yang dikembangkan oleh BUMDES telah dipromosikan pada kegiatan PRUKADES EXPO 2017 yang dilaksanakan di Thamrin City jakarta pada tanggal 28-30 Juli 2017. Walaupun dalam pendampingan tim $\mathrm{IbW}$ 
harus melakukan pendampingan secaracontinue(terus-menerus)sampai masyarakat terampil, kreatif, dan inovatif mengembangkan produk olahan lokal. Produk pancake durian yang dikelola oleh Bumdes Kinaapian desa Batu mulai diperkenalkan pada kegiatan Pasar Lelang Komoditi Agro Periode Ke-6 yang diselenggarakan oleh Dinas Perindustrian dan Perdagangan Provinsi Sulawesi Utara di Hotel Peninsula Manado pada tanggal 10 Agustus 2017.

5. Mendampingi masyarakat dalam sistem budidaya dan membuahkan tanaman durian di luar musim berbuah dengan melakukan pemupukan yang menggunakan ZPT (zat pengatur tumbuh) yang dapat mempercepat proses pembungaan dan pembuahan. Sistem pemupukan tanaman durian lokal dilakukan dengan menggunakan alat mekanisasi penyemprot sprayer yang dapat menjangkau stomata daun sebagai sumber makanan tanaman.

6. Mendampingi masyarakat dalam mengolah limbah kotoran sapi menjadi energi alternatif biogas untuk rumah tangga dan pupuk cair organik yang bermanfaat bagi pertanian. Masyarakat desa Batu dan desa Werot merupakan masyarakat bermata pencaharian sebagai petani berkebun juga mengembangkan peternakan sapi sebagai alat transportasi yang menunjang sektor pertanian/perkebunan dan perekonomian masyarakat. Sistem peternakan di kedua desa ini masih bersifat konvensional atau tradisional yaitu sistem melepas sapi di areaarea perkebunan untuk memperoleh kualitas pakan sapi dengan sistem berpindah tempat pada pagi hari dan sore hari. Masyarakat belum menggunakan sistem perkandangan dengan sistem budidaya pakan yang terencana, sehingga efisiensi waktu dan tenaga yang efektif berkualitas belum tercapai di kedua desa ini..

7. Mendampingi masyarakat dalam meningkatkan peternakan ayam petelur dan pedaging. Masyarakat didampingi untuk mengelola sistem produksi, pemasaran, dan pembukuan sederhana sehingga menghasilkan ekonomi produksi. Pada kelompok ayam petelur desa Werot masih terdapat kendala dalam memahami sistem produksi, sehingga tim pengabdian kepada masyarakat IbW terus-menerus melakukan pendampingan yang intensif sampai pada tahap produksi dan pemasaran. Pada kelompok ayam pedaging dan petelur desa Batu, masyarakat lebih mandiri dan aktif melakukan pengembangan sistem ternak ayam, sekalipun mengalami kendala dalam pengembangan karena serangan virus yang memusnahkan beberapa ekor ayam. Hal ini 
menjadi bahan evaluasi bagi tim IbW dalam mengevaluasi kondisi lingkungan sekitar area budidaya ternak ayam dalam upaya adaptasi pengembangan budidaya.

8. Penguatan Kelembagaan melalui Pemberdayaan Masyarakat, telah dilakukan melalui alih teknologi tepat guna pada industri rumah tangga pengolahan hasil pertanian adalah pembuatan keripik pisang, dan pancake durian. Kelompok wanita tani dapat menerapkan teknologi yang diberikan secara benar dengan kualitas yang memadai serta sudah mulai menjalankan usahanya, terutama penjualan pancake durian.

\section{KESIMPULAN}

Hasil evaluasi pelaksanaan kegiatan menunjukkan bahwa program IbW Tahun I di Kecamatan Likupang Selatan mendapatkan respon yang sangat positif dari pihak terkait seperti masyarakat sasaran, kepala desa, camat dan Satuan Kerja Pemerintah Daerah (SKPD) yang terkait dengan kegiatan IbW. Ada beberapa alasan yang mendorong kondisi tersebut diantaranya: (1) program IbW membawa manfaat yang berarti bagi masyarakat terutama transfer terapan Ipteks kepada masyarakat karena sesuai dengan kebutuhan masyarakat dan tepat guna; (2) Metode dan strategi pemberdayaan masyarakat yang dilaksanakan pada kegiatan ini terutama pendampingan dirasakan sangat efektif oleh masyarakat, dan (3) Keterlibatan berbagai unsur dalam tim dan kepala desa mampu menciptakan sinergisme antara komponen yang bersangkutan sehingga pemberdayaan berjalan intensif dan produktif yang berimplikasi kepada keberlanjutan dari program yang dilakukan.

\section{KEPUSTAKAAN}

Bappelitbang. 2013. Rencana Kerja Pembangunan Daerah (RKPD) Kabupaten Minahasa Utara. Badan Perencanaan Pembangunan Penelitian dan Pengembangan.

I Ketut Karta Dinata, dkk. Pemberdayaan Potensi Masyarakat Dalam Pengembangan Pariwisata Berbasis Pertanian di Kecamatan Petang Kabupaten Badung, Bali. Aplikasi Ipteks Ngayah, 2(2), 2011, 67-77

Katalog BPS. 2012. Statistik Daerah Kecamatan Likupang Selatan. BPS Kabupaten Minahasa Utara Kecamatan Likupang Selatan

Kementerian Desa, Pembangunan Daerah Tertinggal, dan Transmigrasi Republik Indonesia. 2015. Badan Usaha Milik Desa, Spirit Usaha Kolektif Desa.

Kementerian Desa, Pembangunan Daerah Tertinggal, dan Transmigrasi Republik Indonesia. 2015. Perencanaan Pembangunan Desa.

Kuswandoro, W.E. Strategi Pemberdayaan Masyarakat Desa Berbasis Partisipasi. http://wkwk.lecture.ub.ac.id/2015/10/strate gi-pemberdayaan-masyarakat-desaberbasis-partisipasi/jumat 14 juli 2017 10:55 Wita 
Jurnal ABDIMAS, Vol. 10, No. 2, Desember 2017

ISSN: 1979-0953

\section{UCAPAN TERIMA KASIH}

Kami sampaikan terima kasih kepada Direktorat Riset dan Pengabdian Masyarakat, Direktorat Jenderal Penguatan Riset dan Pengembangan Kementerian Riset, Teknologi, dan Pengabdian Tinggi yang telah mempercayakan kami melaksanakan kegiatan Ipteks bagi Wilayah di Kabupaten Minahasa Utara Provinsi Sulawesi Utara. Semoga kerja dan pengabdian ini bermanfaat bagi peningkatan manusia guna mencapai kesejahteraan masyarakat dan penguatan pengembangan wilayah pedesaan. 